\title{
Ophthalmic Sites Cancer TNM Finding v8
}

National Cancer Institute

\section{Source}

National Cancer Institute. Ophthalmic Sites Cancer TNM Finding v8. NCI Thesaurus. Code C140469.

A finding about one or more characteristics of ophthalmic sites cancer, following the rules of the TNM AJCC v8 classification system. 